\title{
Aspects of the formation and development of innovation infrastructure in Ukraine
}

\author{
Iryna Kinash $^{a^{*}}$, Uliana Andrusiva ${ }^{a}$ Olena Golovnia ${ }^{b}$ and Iryna Popadynets ${ }^{a}$
}

${ }^{a}$ Ivano-Frankivsk National Technical University of Oil and Gas, Ukraine

${ }^{b}$ Vinnytsia National Agrarian University, Ukraine

\section{CH R O N I C L E}

\section{Article history:}

Received: June 152019

Received in revised format: June

152019

Accepted: July 8, 2019

Available online:

July 8, 2019

Keywords:

Innovations

University

Innovation infrastructure

Region

Cluster

Public-private partnership

\section{A B S T R A C T}

\begin{abstract}
The article aims at finding ways to intensify the innovation activity of the Ukrainian economy, determine the role of university education in the formation and development of innovation infrastructure. It is substantiated that science and education are a reliable segment for the diffusion of innovations. The best practices of Ukrainian universities on the commercialization of innovative developments and technology transfer in the domestic and foreign markets are presented. The article analyzes the main indicators of the development of innovation activity in Ukraine as well as the dynamics of the development of university education. Particular attention is paid to the role of state classical universities in maintaining innovation development of the state and its regions. It is determined that in modern conditions, universities become integrators, participants, intermediaries, catalysts of communications and cooperation of educational and scientific structures with production, cultural institutions and regional authorities. It was investigated that on the basis of universities, 20 scientific parks have been created and are successfully functioning in Ukraine. The present innovative educational and production cluster of public-private partnership is presented. The scheme of management of it is offered. The results of calculating the multiplicative effect from the development of innovation infrastructure, which will be created as a result of the functioning of the educational-production cluster, are presented. The effectiveness of its influence on the development of the region's economy is proved.
\end{abstract}

(C) 2019 by the authors; licensee Growing Science, Canada

\section{Introduction}

The dynamics of life in the modern world explains the special interest of society in innovation and innovation activity. The practical application of new ideas in the form of new goods and technology has become a powerful driving force for economic and social development. Innovative activity has led humanity to a new, higher degree of development. This, in turn, intensified the processes of globalization of society, led to rapid changes in technology, as well as the constant search for new approaches to management by business entities. For Ukraine, that aims to continue integrating into the world economic space, but in recent years has largely lost its scientific and innovative potential, activation of innovation activity is of particular importance. Fulfillment of innovative potential involves complex modernization of the national economy. Achieving this goal is possible through the mutual integration of such socioeconomic links as "science-education-production". This kind of cooperation will make it possible to 
generate ideas, produce products and provide services that will be competitive on the world market. Such an economic necessity requires institutional transformation of the domestic economy, in particular through the creation and efficient functioning of the innovation network - the innovation infrastructure. The beginning of functioning of this network is associated with the construction of its segments: special economic zones, priority development areas, technology parks, business incubators and other structures.

The importance of the innovation infrastructure development is driven by structural transformations in the state's economy; the need for new knowledge and technologies; the necessity to preserve and develop the scientific and technical potential and innovative entrepreneurship, preventing the leakage of intellectual property and scientific personnel abroad, increasing the effectiveness of scientific activity; solving problems with creating new jobs; formation of the market of innovations. The development of the innovation network in Ukraine is largely determined by the role and place of education, namely universities. They are able not only to generate new ideas and implement them, but also to act as organizers of innovation infrastructure. In modern conditions, universities must become integrators, actors, intermediaries, catalysts of communication and cooperation of educational and scientific structures with production, cultural institutions, and regional authorities. All this indicates that the educational, scientific and entrepreneurial activity of universities and a comprehensive approach to its improvement are the potential of innovation activity in Ukraine.

\section{Literature review}

The issues of the development of innovation infrastructure are considered in the studies of both domestic and foreign authors. The researches of Ukrainian economists in recent years substantiate the conclusion that the level of development of innovation infrastructure is insufficient (Tyuha \& Kuznetsova, 2015; Andreyev, 2018; Melnichenko, 2018; Dovgal et al., 2017). The problem of innovation development is relevant for countries with different levels of economic development. In particular, a scientist from Myanmar links innovation development with innovation and research skills (Sinha, 2018). Scientists from Serbia believe that in the world there was a reorientation of key aspects of economic development (Katić et al., 2016). It has been shown that resources, eco-efficiency and innovation have become key elements for achieving national goals. Education is considered the strategic resource in achieving goals. Strong evidence that knowledge should integrate innovation is labor (Guo et al., 2019), in which the authors, after analyzing data from 295 entrepreneurs and top managers in Chinese high-tech new businesses, found that both the coherent integration of knowledge and the system integration of knowledge have a positive effect on high-tech productivity and innovation activity. The study of the impact of various indicators related to knowledge economy on the country's competitiveness in the European Union (EU) became the subject of a study by Dima et al. (2018). It was determined that the development of EU policies on learning opportunities throughout the life of the European workforce and focusing on research and development can significantly contribute to the competitiveness of EU Member States. Scientists from Latvia (Bikse et al., 2018) conducted research on the creation of innovative enterprises. They also considered the implementation of startups and linked the concept of startup with business incubation, indicating the prospects for the development of innovation infrastructure in the country.

Mousavi et al. (2013) emphasized the importance of cooperation between the state, industry and the university. The authors argue that cooperation encourages the development of new technologies in all sectors of the economy and various firms, as well as contributes to the development of information infrastructure. Poszytek and Jezowski (2018) argue that in a world driven by innovation, collaboration between academia and business is a prerequisite for sustainable economic growth. The authors propose a methodology for calculating the activity index of higher education and business, which includes a set of indicators that determines how universities in different countries cooperate with industry and business. Russian scientists devoted their researches to cooperation of universities with high-tech enterprises (Fomina \& Makolski, 2017). 
The cooperation is emphasized by Nosova et al. (2018) and it is believed that cooperation repeatedly multiplies the productivity of existing factors of production and serves as the main mechanism for balancing the economy. Under these conditions it is expedient to form an innovative territorial cluster, which will promote the development of both innovative entrepreneurship and the successful implementation of joint initiatives. Ivanov and Tyshchenko (2015) prove the urgency of the development of public-private partnership, which can become the institute of accelerated innovation development of the economy through the division of the state (public sector) and the multiplier effect of business (private sector). Marozau et al. (2016) focused on the potential of universities. They proved that the innovative development of countries and regions is based on the knowledge provided by education. The capital created by universities is a major factor in economic development. The readiness of education for change, as well as the problems of management are emphasized in the study by Turginbayeva et al. (2018). Scientists argue that different educational processes take place in education: new types of educational institutions are created; educational institutions become independent not only financially but also educationally, which also contributes to the use of the potential of innovation activity. Guerrero et al. (2015) argue that the university acts as a transmission channel that promotes economic and social development through its numerous missions in teaching, research and entrepreneurship.

The scope of the implementation of innovations largely depends on the resource provision of education. The presence of such problems was witnessed by the work of Drape et al. (2016) and Kinash (2015)

The article aims at finding ways to intensify the innovation activity of the Ukrainian economy, determine the role of university education in the formation and development of innovation infrastructure.

\section{Results and discussion}

Innovation activity determines the economic growth of each state. The drivers of innovation processes are business and education. Let us consider the main indicators of innovation development in Ukraine. For the period 2008-2017, we observe heterogeneous tendencies. Research evidence suggests that at the beginning of 2018, 963 organizations carried out research and development in Ukraine, which is 30\% less (Table 1).

Table 1

Science, technology and innovation in Ukraine

\begin{tabular}{|c|c|c|c|c|c|c|}
\hline year & $\begin{array}{c}\text { Number of } \\
\text { organizations } \\
\text { that carry out } \\
\text { research and } \\
\text { development }\end{array}$ & $\begin{array}{l}\text { Number of } \\
\text { scientific } \\
\text { personnel, } \\
\text { persons }\end{array}$ & $\begin{array}{l}\text { Share of the } \\
\text { volume of sci- } \\
\text { entific and } \\
\text { scientific and } \\
\text { technical } \\
\text { work per- } \\
\text { formed in } \\
\text { GDP, \% }\end{array}$ & $\begin{array}{l}\text { Sources of financ- } \\
\text { ing of innovation } \\
\text { activity at the ex- } \\
\text { pense of state } \\
\text { budget funds, mil- } \\
\text { lion. }\end{array}$ & $\begin{array}{l}\text { Sources of financ- } \\
\text { ing of innovation } \\
\text { activity at the ex- } \\
\text { pense of foreign } \\
\text { investors' funds, } \\
\text { UAH million. }\end{array}$ & $\begin{array}{l}\text { Share of sales of } \\
\text { innovative prod- } \\
\text { ucts in the vol- } \\
\text { ume of industrial } \\
\text { ones, } \%\end{array}$ \\
\hline
\end{tabular}

\begin{tabular}{lllcccc}
\hline 2008 & 1378 & 94138 & 0,9 & 336,9 & 115,4 & 5,9 \\
2009 & 1340 & 92403 & 0,95 & 127,0 & 1512,9 & 4,8 \\
2010 & 1303 & 89564 & 0,9 & 87,0 & 2411,4 & 3,8 \\
2011 & 1255 & 84969 & 0,79 & 149,2 & 56,9 & 3,8 \\
2012 & 1208 & 82032 & 0,8 & 224,3 & 994,8 & 3,3 \\
2013 & 1143 & 77853 & 0,8 & 24,7 & 1253,2 & 3,3 \\
2014 & 999 & 69404 & 0,69 & 344,1 & 138,7 & 2,5 \\
2015 & 978 & 63864 & 0,64 & 55,1 & 58,6 & 1,4 \\
2016 & 970 & 63694 & 0,16 & 179,0 & 23,4 & 1,2 \\
2017 & 963 & 59392 & 0,48 & 227,3 & 107,8 & 0,7 \\
\hline
\end{tabular}

Source: compiled on the basis of the Official Site of the State Statistics Service of Ukraine. 
The main sources of financing for innovation activity are the state budget and the funds of investors. It should be noted that 2015-2016 were unfavorable in terms of attracting foreign investors. In our study, we focus on the important role of education in the implementation of innovation. We investigated the role of higher education institutions in the development of innovation activities, which consists of:

- generation of intellectual property objects;

- formation of innovation infrastructure;

- establishing of small, high-tech enterprises at educational institutions;

- training for research and innovation activities and infrastructure;

- formation of innovation culture in the business environment.

It is also important that education is the connecting link in the system "science - education - production". Let us consider the main indicators and trends of the development of education in Ukraine during 20112018 (Table 2).

Table 2

Dynamics of the main indicators of the development of the university education in Ukraine

\begin{tabular}{lccccccccc}
\hline \multicolumn{1}{c}{ Indicators } & 2011 & 2012 & 2013 & 2014 & 2015 & 2016 & 2017 & 2018 & $\begin{array}{c}2018 / \\
\text { 2011, \% }\end{array}$ \\
\hline $\begin{array}{l}\text { Universities, academies, } \\
\text { institutes, units. }\end{array}$ & 345 & 334 & 325 & 277 & 288 & 287 & 289 & 282 & 81,7 \\
$\begin{array}{l}\text { Their students, thousands of } \\
\text { people }\end{array}$ & 1723,7 & 1824,9 & 1723,7 & 1438,0 & 1375,2 & 1369,4 & 1330,0 & 1322,3 & 76,7 \\
$\begin{array}{l}\text { Number of postgraduate stu- } \\
\text { dents, persons }\end{array}$ & 34192 & 33640 & 31482 & 27622 & 28487 & 25963 & 24786 & 22829 & 66,8 \\
$\begin{array}{l}\text { Number of doctoral students, } \\
\text { persons }\end{array}$ & 1631 & 1814 & 1931 & 1759 & 1821 & 1792 & 1646 & 1145 & 70,2 \\
\hline
\end{tabular}

Source: compiled on the basis of the Official Site of the State Statistics Service of Ukraine.

Materials of research indicate that during the studied period, in Ukraine, according to all selected indicators, we see declining tendencies. In particular, the number of universities, academies and institutes decreased by $18.3 \%$; number of students decreased by $22.3 \%$; number of postgraduates decreased by $33.2 \%$; number of doctoral students decreased by $29.8 \%$. The scientific and innovation activity of universities is carried out on the following principles: unity of educational, scientific, innovation processes and connection with the economy and social sphere of the region and the state as a whole; availability of an effective system of management of innovation processes; integration with institutions of education and science, industrial complex; involvement of teachers, staff, graduate students, and students in the innovation process. Under such circumstances, university science in Ukraine is able to maximize innovative results which are important for all the spheres of life in the country. In this context, with the support of the Ministry of Education and Science of Ukraine, the catalog "Innovative developments of universities and scientific institutions" was presented. Innovative developments mean the results of scientific and research work or independent initiative researches in the form of newly created and (or) improved competitive technologies, products or services, which significantly improve the structure and quality of production and (or) social sphere, and which are protected as an object of intellectual property rights, or are implemented through a licensed agreement as know-how (Strika \& Ilchenko, 2017). In our opinion, information about the experience of universities in the commercialization of innovative developments and technology transfer on the domestic and foreign markets is interesting. In the national university environment, urban infrastructure for innovation support is formed, which includes business incubators, technology parks, business support funds, information and advisory agencies, business accelerators and start-up schools (Fig. 1). 


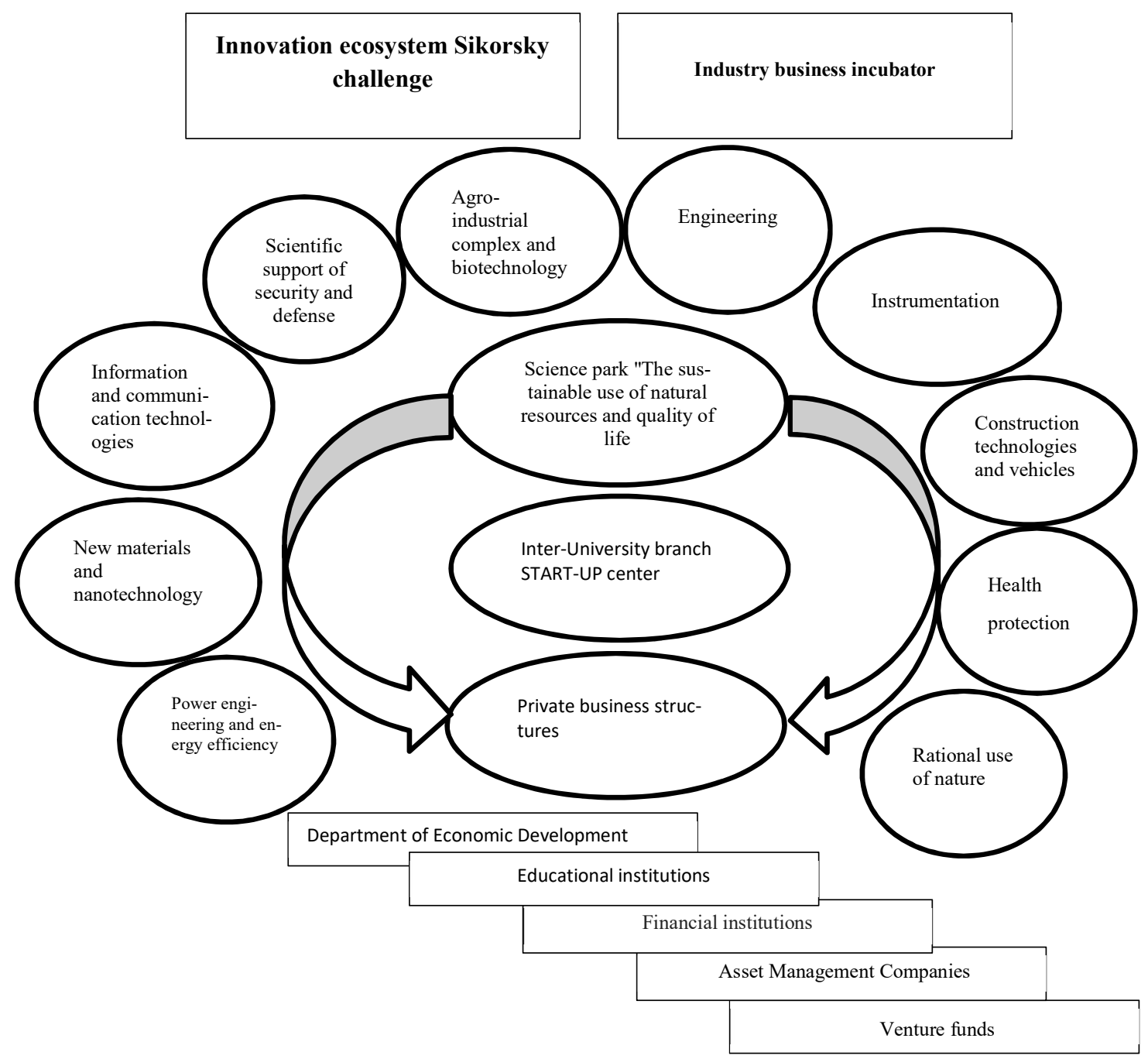

Fig. 1. Innovation educational and production cluster of public-private partnership

Source: proposed by the authors

It supports startup projects at the initial stages, including providing jobs, initial investment, technical expertise, coaching services, mentoring, and the ability to join the ecosystem - friendly community, united by common interests. This allows to create favorable environment for startups which combine different industries, to provide success of the first companies, which will be able to involve new members. Innovation performance in universities is an integral part of educational performance and is aimed at the creation and introduction of new competitive technologies, equipment, materials, etc. to provide innovative development of the society, trainings of innovative specialists. Research and innovation performance in universities is multifaceted and is considered from the point of view of ensuring high quality of training those who want to obtain higher education, as permanent source of updating the education and obtaining new scientific knowledge, as well as developing new technologies, samples of new products in order to accelerate the development, production and implementation of modern high-tech products, technology transfer on the domestic and foreign markets. The greatest achievements has the innovative ecosystem Sikorsky Challenge of Kiev Polytechnic Institute. Historically, the first scientific park was created here. The purpose of its performance was the implementation of measures concerning the intensification processes of the development, production and introduction of scientific and competitive products on the domestic and foreign markets. In fact, this university initiated the organization of innovation performance in higher educational establishments on the basis of the combination of interests of 
all its participants, namely: the education, science, government and business. The experience of this university was used in the adoption of the Law of Ukraine ("About Scientific Parks", 2012), and afterwards similar parks were created in 20 other Ukrainian universities. The sphere of innovation and communication technologies is the most widespread activity of scientific parks (13\%).

Science parks play an important role in the socio-economic development of the country, in particular: increase employment and share of highly skilled personnel; provide high economic efficiency and profitability of high-tech enterprises; promote economic growth of the backward regions and the development of scientific and technological agglomerations; distribute new technologies; reorganize production and management processes through informatization and computerization. The innovative ecosystem Sikorsky Challenge is designed to select, involve and educate creative people to develop their own business, to help the participants find investors and promote startups. The priority directions of the innovative ecosystem "Sikorsky Challenge" are as follows:

- involving and selecting creative people, who want to be engaged in innovative entrepreneurship, inventors, scientists, postgraduates and university students, research institutes, as well as business representatives;

- teaching the selected participants innovative entrepreneurship, motivating them to form their own technological ideas; growing business ideas, assisting participants in developing projects and creating prototypes of business products;

- searching for the investors / business angels to invest in promising projects (first and second round of investments);

- selecting the best start-up projects with the participation of trainers, experts of funds, investors, business angels; organizing and conducting the innovative business project competition during the fest "Sikorsky Challenge";

- helping participants - authors of the ideas to "tighten up" selected start-up projects with interested investors;

- participating in starting and launching startup companies;

- assisting and supporting intellectual property rights protection (registration of copyrights, patents, licenses);

- providing legal, organizational, accounting support of the start-up company up to the second round of investments;

- assisting in launching the startup company to the international level.

The research of the organization of innovation performance in certain universities indicates shows that startups regularly involve investments from the local and global investors. According to the Ukrainian Association of Venture Capital and Direct Investments (UAIB), in Ukraine there are about 3000 startups, in which 34 venture funds agree to invest (Analytical review of the market of collective investment institutions in Ukraine, 2017). State classical universities play special role in the innovation development of the state and its regions. They carry out the mission of uniting professional education, science and culture of the region. Classical university, located in the center of the unified educational space of the region, is the most important social informal institution which can initiate the formation of the innovation infrastructure of the region and influence development of the economy. Institutional "informality" is an integral component of any society, and it forms a subsystem of informal institutions. However, it can be of different forms and can have different consequences from the standpoint of influence on formal institutions, economic behavior and economic performance of various subjects (Douglas, 1997). Such informal institute can provide harmony and compromise in the interactions among the state and municipal authorities, scientific institutions, educational centers of universities, financial institutions, business incubators, venture funds, consulting firms, associations of entrepreneurs. For innovative development of the regions (we chose Ivano-Frankivsk, Dnipropetrovsk, Kyiv and Kharkiv regions), it is advisable to use cluster approach, which means the introduction of the informal interaction, partnership, cooperation, 
dialogue among the interested subjects. This approach coincides with the notion of the effective cluster policy of Andersson et al. (2004), who considers it to be an "umbrella brand" for the unification of the traditional development directions during the choice of the common strategic development vector.

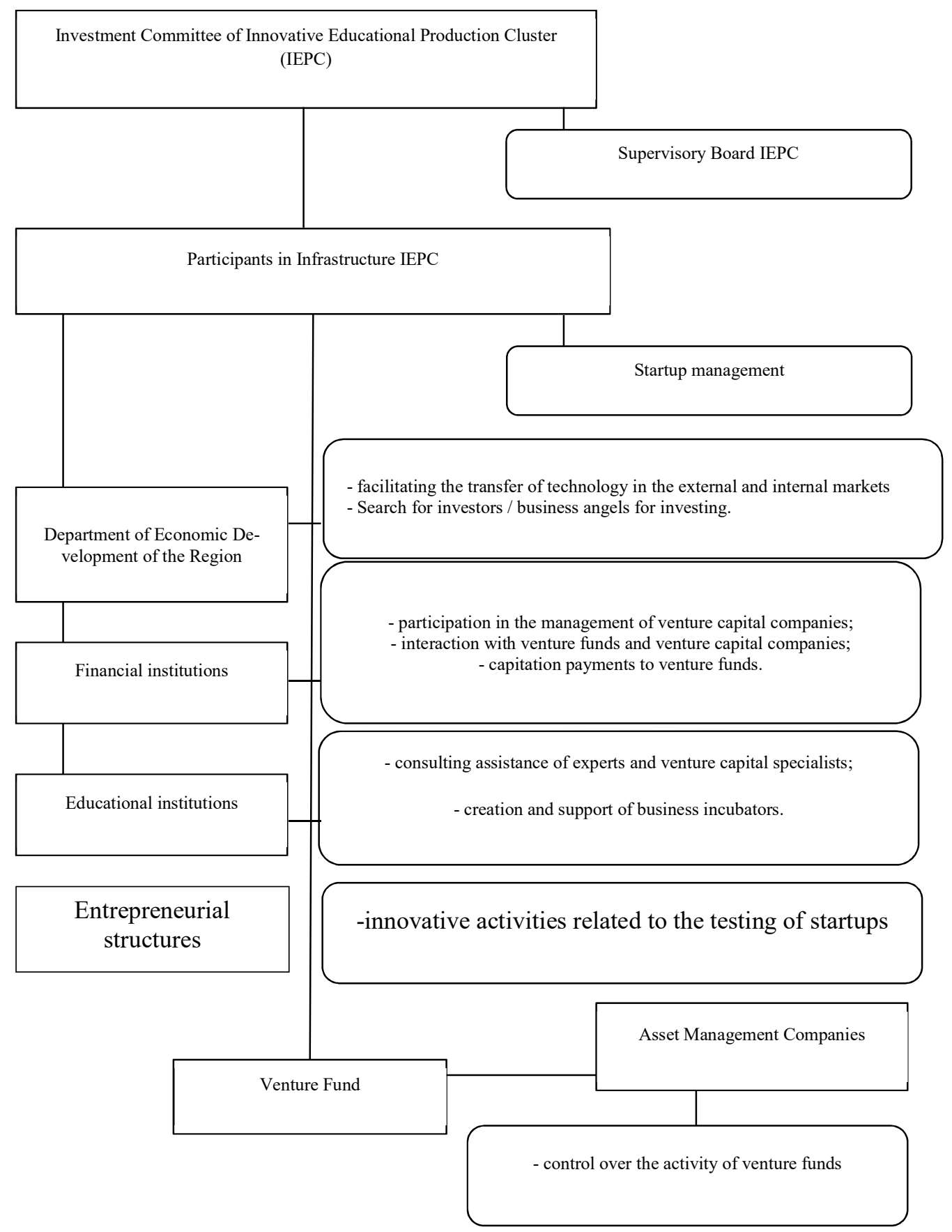

Fig. 2. Innovative educational and production cluster management scheme

Source: proposed by the authors 
On this basis, we note that an innovative educational-production cluster (Fig. 1) began to operate in Ukraine, which was developed in an effective form of public-private partnership as a multilateral treaty union of business entities without pooling of deposits, namely: state authorities, educational establishments and scientific institutions, professional organizations, financial institutions and private entrepreneurial structures, in which conditions are created to stimulate educational, scientific, innovative, financial and economic activity, the exchange of knowledge and experience, and the promotion of the efficient transfer of technologies and information through joint opportunities, the expansion of professional competences in accordance with the didactic, technological and mental aspects. Materials of research indicate the existence of difficulties in its management. We have proposed a scheme for managing an innovative educational and production cluster (IEPC) with the indication of the functions assigned to each unit of the structure, presented in Fig. 2. It demonstrates an ordered set of interconnected elements that are interrelated in a stable relationship that ensures their operation and development. The elements of the structure are: the investment committee of the innovative education and production cluster, which consists of venture capital investors, supervisory board, asset management company. Relationships among them are maintained through the communication, due to which management process takes place. This process consists of information flows and management decision making, tasks and functions are divided among them, as well as management rights, and the responsibility for their implementation. Consequently, management structure can be researched as the interaction and distribution process of management performance, within which management process takes place, which is aimed at solving current problems in accordance with certain purposes.

The organizational structure of management can be changed under the influence of internal and external environment factors. To estimate the effectiveness of functioning of the suggested cluster, the indicators which reflect urban structure of managing the innovative educational and production cluster, were arranged. Five indicators were chosen which particularly show the effectiveness of hierarchical and functional constituents of management structure as one of the stages of the analysis of the innovative educational and production cluster venture performance.

$$
R_{t f}=\frac{P}{C_{m}}
$$

where $\mathrm{R}_{\mathrm{ef}}$ - coefficient of efficiency of innovation educational and production cluster (IEPC); $\mathrm{P}-$ the end result of IEPC functioning; $\mathrm{C}_{\mathrm{m}}$ - total administrative and managerial expenses of IEPC.

$$
R_{f c}=\frac{C_{m d}}{C},
$$

where $\mathrm{R}_{\mathrm{fc}}$ - the cost factor for the management decisions of the IEPC infrastructure; $\mathrm{C}_{\mathrm{md}}-$ total administrative and managerial costs of the IEPC infrastructure; $\mathrm{C}$ - total cost of the IEPC infrastructure activity.

$$
R_{f i}=\frac{I_{z}}{I_{d}}
$$

where $\mathrm{R}_{\mathrm{fi}}$ - IEPC infrastructure managerial validity ratio; $\mathrm{I}_{\mathrm{z}}$ - the volume of the analyzed information for making managerial decisions in $\% ; I_{d}-$ the required amount of information for making managerial decisions in $\%$ of the total amount of information.

$$
R_{t e}=\frac{Z_{l}-Z_{e}}{Z},
$$

where $\mathrm{R}_{\text {te }}$ - compliance ratio of IEPC infrastructure solutions that promote venture capital investment in the region's economy; $Z_{1}$ - the number of decisions taken by the IEPC infrastructure managerial staff, which facilitate the attraction of venture investments in the region's economy; $Z_{e}-$ the number of 
decisions taken that do not contribute to the attraction of venture investments in the region's economy, units. $\mathrm{Z}$ - total number of decisions taken.

$$
R_{r}=\frac{P_{r} \times O_{r}}{R_{v}}
$$

where $\mathrm{R}_{\mathrm{r}}$ - risk factor for IEPC infrastructure managerial decisions; $\mathrm{P}_{\mathrm{r}}$ - probability of occurrence of risk while making and implementation of management decision, share; $\mathrm{O}_{\mathrm{r}}-$ amount of possible expenses as a result of the adoption and implementation of the management decision, thousand $U A H ; R_{V}-$ costs for the formation of methods for reducing the level of risk, thousand UAH. On the basis of the received calculations, an integral indicator of the efficiency of the innovation educational and production cluster functioning was determined (Table 3 ).

Table 3

Indicators of the efficiency analysis of the innovation educational and production cluster functioning for 2013-2018

\begin{tabular}{|c|c|c|c|c|c|c|}
\hline \multirow{2}{*}{ Indicator } & \multicolumn{5}{|c|}{ Estimated value } & \multirow[b]{2}{*}{2018} \\
\hline & 2013 & 2014 & 2015 & 2016 & 2017 & \\
\hline $\begin{array}{l}\text { The coefficient of efficiency of the innovation } \\
\text { educational and production cluster (IEPC) }\end{array}$ & 0,4 & 0,45 & 0,45 & 0,9 & 1 & 0.96 \\
\hline Cost factor for IEPC management decisions & 0,85 & 1,1 & 1,00 & 2,4 & 1,2 & 1,4 \\
\hline $\begin{array}{l}\text { The coefficient of validity of IEPC management } \\
\text { decisions }\end{array}$ & 0,65 & 0,7 & 0,75 & 0,4 & 0,65 & 0,73 \\
\hline $\begin{array}{l}\text { Coefficient of compliance of the adopted IEPC } \\
\text { decisions, which promote attraction of venture } \\
\text { investments in the region's economy }\end{array}$ & 0,3 & 0,2 & 0,46 & 0,35 & 0,9 & 0,87 \\
\hline $\begin{array}{l}\text { Risk factor of administrative IEPC infrastructure } \\
\text { decisions }\end{array}$ & 1 & 1 & 1,3 & 1,5 & 1 & 1,1 \\
\hline $\begin{array}{l}\text { Integral indicator of the efficiency of the functioning of } \\
\text { innovation IEPC infrastructure }\end{array}$ & 0,5812 & 0,5863 & 0,7261 & 0,8538 & 0,931 & 0,947 \\
\hline
\end{tabular}

Source: calculated by the authors on the basis of (Venture financing, 2017).

The next step is to calculate the multiplier effect of infrastructure development and to prove the effectiveness of its impact on the development of regional economy. The mechanism of the innovation multiplier is based on the fact that an additional change in investments in the innovations of some business units becomes the income of other economic entities, received as payment for innovative goods and services. This income takes part in many transformations and is gradually reduced by the amount of savings and is given as a payment for consumer expenses to another entity of the innovation economy, etc. (Venture financing, 2017). Thus, the more the inclination to invest in innovations is, the greater the multiplier effect. The mechanism of the innovation multiplier of the region is based on the increase of the material reward for workers (average wages). Accordingly, the initial increase in investment costs generates chain reaction of the increase in regional income and its consumer expectations and, as a result, leads to an increase in the welfare of the society. To calculate the multiplier of innovations of the region, the following indicators are used: the indicator of average wages at regional level, the integral indicator of the effectiveness of infrastructure of innovation performance management and the expected increase of venture investment in conditions of a certain consumer demand of the region. Let us consider the mechanism for evaluating the multiplier effect. The multiplier effect is calculated with the formula:

$$
\Delta Y=\frac{K}{\Delta V S}
$$

where $\Delta \mathrm{Y}$ - average wage growth at regional level; 
UI - integral indicator of the effectiveness of IEPC innovation infrastructure functioning; $\Delta$ VS - forecasted increase in venture investment in conditions of a certain consumer demand of the region;

Organizational innovations multiplier

$\mathrm{K}$ - multiplicative coefficient of innovations of the region, where

$$
K=\frac{1}{1-Y I}
$$

In Table 4 and Fig. 3 you can see the data showing the results of calculations of the multiplier effect of the development innovation infrastructure and the effectiveness of its influence on the development of regional economy.

\section{Table 4}

Indicators which are used to estimate the multiplier effect of the analysis of the effectiveness of IEPC innovation infrastructure functioning (2013-2018)

\begin{tabular}{|c|c|c|c|c|c|c|}
\hline Indicator & 2013 & 2014 & 2015 & 2016 & 2017 & 2018 \\
\hline Average wages in the region, UAH & 3250 & 3596 & 4653 & 5499 & 6680 & 8334 \\
\hline Venture financing, UAH million & 89 & 39 & 132 & 88 & 258,6 & 342,5 \\
\hline $\begin{array}{l}\text { Integral indicator of the efficiency of } \\
\text { innovation infrastructure functioning } \\
\text { IEPC }\end{array}$ & 0,5812 & 0,5863 & 0,7261 & 0,8538 & 0,9317 & 0,9485 \\
\hline $\begin{array}{l}\text { The coefficient of innovation in the re- } \\
\text { gion }\end{array}$ & 2,3878 & 2,4172 & 3,6510 & 6,831 & 14,64 & 15,1 \\
\hline
\end{tabular}

Source: calculated by the authors on the basis of (Venture financing, 2017).

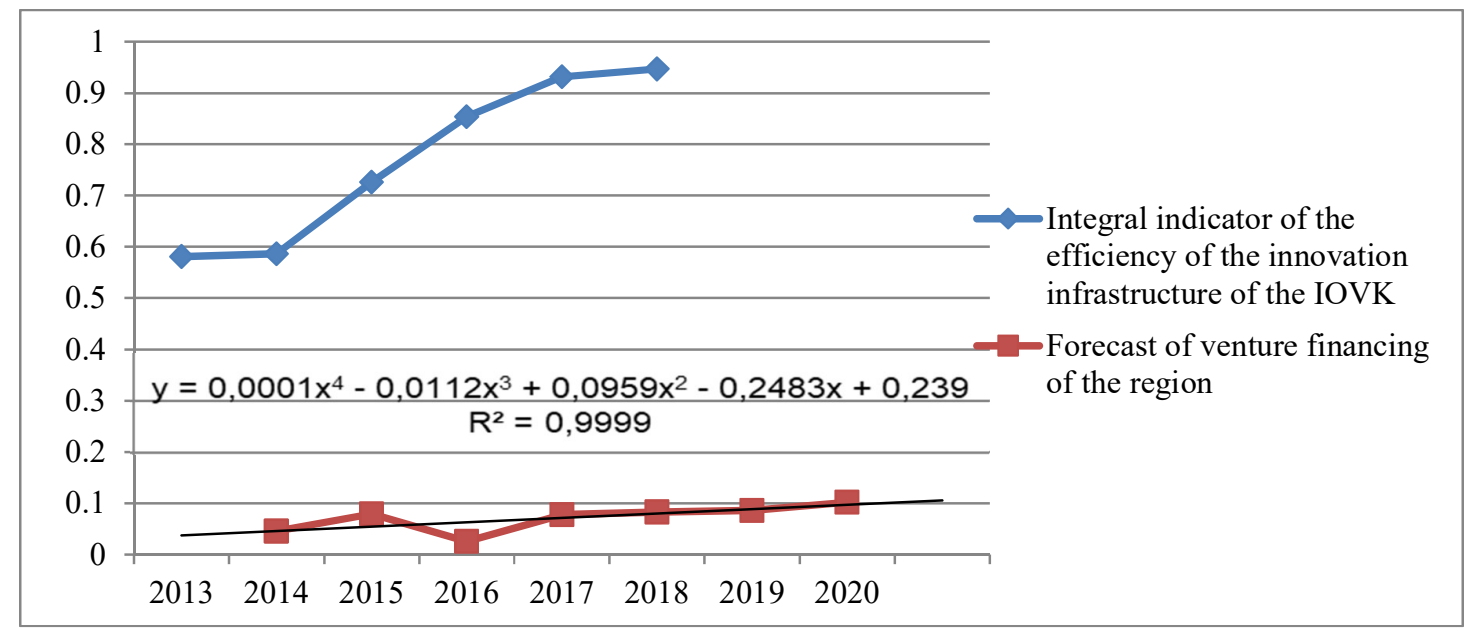

Fig. 3. Multiplicative effect of innovation infrastructure in the region

Source: formed by the authors

\section{Conclusion}

Current situation of socio-economic development of Ukraine underlines the role of the components of the national innovation system, which serves as the formation and support for innovative technology companies. Venture investment institutes are considered to be one of the most effective tools for the involvement of investments in European countries. World experience says that venture capital investment is most likely to be formed in the creative environment of universities. To activate venture investments at the state level, it is suggested to strengthen the activities of creating favorable conditions for the gen- 
eration of business ideas and their transformation into innovations which may be demanded by the investment community. Science and education segment is good for such diffusion of innovations. It was determined that in the environment of national universities, urban infrastructure for the support of innovators has already been formed. It includes business incubators, technology parks, business support funds, information and advisory agencies, business accelerators and start-up schools. The innovative cluster of public and private partnership and its participants is presented in Ukraine. The achievements of Kiev Polytechnic Institute are emphasized, which managed to combine the interests of all the participants, such as education, science, government and business, and created the innovative ecosystem "Sikorsky challenge". Its purpose is the selection, involvement and teaching creative people so that they could create their own businesses and startups. This system can also help the participants find investors and promote start-ups. The creation of a cluster will contribute the innovative development of the state and its regions. The innovation and production cluster management scheme is suggested. It will be in the form of public and private partnership among state authorities, educational and scientific institutions, professional organizations, financial institutions and business structures. The functioning of such cluster is estimated. The multiplicative effect of the development of innovation infrastructure of the region is calculated (Ivano-Frankivsk, Dnipropetrovsk, Kyiv and Kharkiv regions). It is proved that cluster development will increase the growth of venture investments in regional economy.

\section{References}

Analytical review of the market of collective investment institutions in Ukraine. (2017). URL: http://www.uaib.com.ua

Andersson, T., Schwaag-Serger, S., Sorvik, J., \& Hansson, E.W. (2004). The Cluster Policies Whitebook. Malmö, Sweden: IKED International Organization for Knowlwdge Economy and Enterprise Development. URL: http://www.clusterplattform.at/fileadmin/user_upload/clusterbibliothek/916

Andreyev, V. (2018). Problems of financing innovative development of Ukraine and ways of their solution. Materials of the XI International Business Forum, Kyiv: Kyiv. nats Trade.Ekonom. un-t, pp. 1517.

Bikse, V., Lusena-Ezera, I., \& Rivza, B. (2018). Innovative start-ups: challenges and development opportunities in Latvia. International Journal of Innovation Science, 10(2), 261-273.

Dima, A., Begu, L., Vasilescu, M., \& Maassen, M. (2018). The relationship between the knowledge economy and global competitiveness in the European Union. Sustainability, 10(6), 1706.

Douglas, N. (1997). Institutions, institutional changes and functioning of the economy. Per. from english AN Nesterenko; prelude And teach Ed. BZ Miller - M .: Fund of the economic book "Beginning", 180 p., P. 56

Dovgal, O. V., Kravchenko, M. V., Demchuk, N. I., Odnoshevnaya, O. A., Novikov, O. Y., Andrusiv, U. Y., \& Popadynets, I. R. (2017). Methods of competitiveness assessment of agricultural enterprise in Eastern Europe. Regional Science Inquiry, 9(2), 231-242.

Drape, T. A., Rudd, R., Lopez, M., \& Radford, D. (2016). Challenges and solutions to higher education institutions in Africa. International Journal of Education, 8(1), 43-58.

Fomina, I. G., \& Makolski, M. S. (2017, February). Strategic partnership of universities and high-tech enterprises by the example of the innovative project "RFID systems (RFID) identification of vehicles». In 2017 IEEE Conference of Russian Young Researchers in Electrical and Electronic Engineering (EIConRus) (pp. 1332-1336). IEEE.

Guerrero, M., Cunningham, J. A., \& Urbano, D. (2015). Economic impact of entrepreneurial universities' activities: An exploratory study of the United Kingdom. Research Policy, 44(3), 748-764.

Guo, R., Cai, L., \& Fei, Y. (2019). Knowledge integration methods, product innovation and high-tech new venture performance in china. Technology Analysis and Strategic Management, 31(3), 306-318.

Ivanov, Y., \& Tyshchenko, V. (2015). Public-private partnership potential in knowledge economy: Regional aspect. Economic Annals-XXI, 3-4(1), 28-31.

Katić, A. V., Ćosić, I. P., Kupusinac, A. D., Vasiljević, M. M., \& Stojić, I. B. (2016). Knowledge-based competitiveness indices and its connection with energy indices. Thermal Science, 20, S451-S461. 
Kinash, I. P. (2015). Current state of infrastructure provision of education in Ukraine. Actual Problems of Economics, 169(7), 259-262.

Law of Ukraine "On Science Parks". [Electronic resource]. URL: $\underline{\text { http://za- }}$ kon.rada.gov.ua/laws/show/1563-17

Marozau, R., Guerrero, M., \& Urbano, D. (2016). Impacts of universities in different stages of economic development. Journal of the Knowledge Economy, 1-21. doi: 10.1007/s13132-016-0359-7

Melnichenko, O. (2018). Innovative Development of the National Economy: Challenges for the State, Business and the Population. URL: http://www.kbuapa.kharkov.ua/e-book/db/20182/ doc/2/02.pdf

Mousavi, Z., Moeinfar, Z., \& Amouzesh, N. (2013). The role of intellectual capital in knowledge-based economy. Life Science Journal, 10(SUPPL.6), 56-60.

Nosova, S. S., Makar, S. V., Chapljuk, V. Z., Medvedeva, A. M., \& Semenova, A. N. (2018). Collaborative nature of innovative economy. [Naturaleza colaborativa de la economía innovadora] Espacios, 39(41)

Poszytek, P., \& Jezowski, M. W. (2018). The index of higher education-business engagement a methodology of the instrument monitoring university-business relations. Paper presented at the IMCIC 2018 - 9th International Multi-Conference on Complexity, Informatics and Cybernetics, Proceedings, 1 1721.

Sinha, G. R. (2018). Innovation and research skill for knowledge-based economy of myanmar: Current status and recommendation. Journal of Science and Technology Policy Management. doi:10.1108/JSTPM-12-2017-0078

State statistics service of Ukraine, (2018). URL: http://www.ukrstat.gov.ua

Strika, M., Ilchenko, M. (2017). Innovative developments of universities and scientific institutions of the Ministry of Education and Science of Ukraine. Kyiv: Gifted Child Institute, National Academy of Sciences of Ukraine, p. 278.

Turginbayeva, A., Smagulova, G., Ashirbekova, L., \& Malikova, R. (2018). Topical issues of management in modern education and ways to solve them. Paper presented at the Proceedings of the 32nd International Business Information Management Association Conference, IBIMA 2018 - Vision 2020: Sustainable Economic Development and Application of Innovation Management from Regional Expansion to Global Growth, 3643-3647.

Tyuha, I., Kuznetsova, V. (2015). Problems of innovation activity in Ukraine and member countries. Effective economy, № 11. URL: http://www.economy.nayka.com.ua/?op $=1 \& \mathrm{z}=4545$.

Venture financing. URL: http://uvca.eu/ua/news/ukrainian-venture-capital-and-private-equity-overview-2017

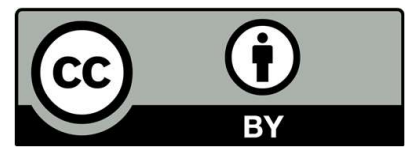

(C) 2019 by the authors; licensee Growing Science, Canada. This is an open access article distributed under the terms and conditions of the Creative Commons Attribution (CCBY) license (http://creativecommons.org/licenses/by/4.0/). 